\title{
Branding the Green Tourism in Macedonia
}

\author{
Biljana Petrevska \\ Goce Delčev University, Faculty of Tourism and Business Logistics, Štip, \\ Macedonia \\ e-mail: biljana.petrevska@ugd.edu.mk
}

\section{Vlatko Cingoski}

\author{
Goce Delčev University, Faculty of Electrical Engineering, Štip, Macedonia \\ e-mail: vlatko.cingoski@ugd.edu.mk
}

\begin{abstract}
Tourism is a fast growing business and therefore developing a national brand can be part of an effective strategy for managing the national growth of tourism. A positive national image is an essential ingredient in the promotion of tourism which raises the issue of investing into the national branding as part of the image-building strategy. The article draws on primary and secondary data to provide insights into the processes and conflicts of branding Macedonia as an eco-friendly destination. The authors examine the hotel management perception of environmental protection and renewable energy sources. The study used (1) quantitative methods by calculating medians in terms of exploring the standard indicators for measuring eco policy and environmental protection practices and (2) qualitative methods, by consulting the secondary data sources. More precisely, an assessment is made on how hospitality industry stakeholders manage the environmental issues as it can directly increase the destination competitiveness. The main objective is to determine the level of environmental quality in Macedonia as a basis for creating a national green tourism brand. The study shows that a large number of hotel industry stakeholders lack measures to reduce the conventional energy use and replace it with renewable energy sources. Although fully aware of the importance of the energy efficiency concept, it is not managerial priority of Macedonian hotels. These findings may help when further steps are taken towards creating marketing strategies to enhance the country's distinctiveness. This article initiates the making of a framework for the introduction of competitive environmental strategies in hotel establishments in order to contribute to Macedonia's green identity.
\end{abstract}

Key words: promotion, branding, environment, green tourism. 


\section{Introduction}

The puzzle, which needs to be done so that the country can be more attractive, poses the issue of initiating the national branding process. It is known that every country has strengths and weaknesses and a good brand may project a country's strengths while recognizing its weaknesses. Therefore, the purpose of branding is to position the country in the best possible way in the world system, giving its strengths and weaknesses, by simultaniously being truthful and believable.

Many countries tried to create and develop branding strategies for their tourist destinations, like: the "Smurf Village" in Júzcar, Spain; "Enjoy Limfjorden" in Jutland, Denmark; "Witches in Southern Spain" in Soportújar, Spain etc. (Real, 2016). All of them tried to promote a context that allows tourists to appreciate what the country has to offer, which actually refers to the overall image or brand. Despite the complexity of the process due to the fact that branding is neither owned nor controlled by a single entity, it contributes to the reputation of the country. However, attention may be paid to the differences that occur when branding a country, a region or a city. While countries should leverage the emotive or representation parts of their brand identity, regions and cities should leverage their more functional facets (Caldwell and Freire, 2004).

Creating and developing a brand is not an easy task, so even developed countries do not find brand management an easy mission. Very few countries have successfully launched a national brand. Its inception evolved from various fields including imaging and communicating. It consists of connecting internationally and externally, based on the country's positive values and perceptions that are relevant to export development. The brand concepts, once researched, tested and defined, are then used as the basis of targeted promotional campaigns, when encouraging tourism development. Due to the globalization process, the competition between countries today affects not only nations and regions, but also cities and even villages, which are competing for the same tourists and visitors. In such environment, no one can think of prosperity unless it knows how to manage business (Kotler et al., 1993). Therefore, marketing is highly dependent on image based on perception, which is a starting point for developing a brand. This provides the basis for developing policy and simultaneously may assist the country to be identified by it. Moreover, branding is a kind of combination of marketing measures and the components of the brand management (Kavaratzis, 2004). It enables to provoke association in the mind for something unique, different, and with a competitive brand value.

Despite the fact that Macedonia has been an independent state for more than two decades, it seems that it is still trapped in its transition period and still strives for creation of some new patterns. There is a lack of global image and bad prejudice, which may be a good sign and a rare opportunity if the country may start to build the brand in its own way. Macedonia is among the new comers and latest arrived. As a little-known country, it may have the greatest opportunity to establish a brand from scratch. Hence, building a position on new markets requires time, but the fact to be a brand new destination can be the key asset to go faster and more efficiently 
in building awareness in tourists' perception. In such a dynamic context, the way out is detected in favoring tourism as a possibility to enhance national economy. The rapid expansion in the past few years in terms of number of tourists, caused tourism to be recognized as one of the national strategic priority areas in Macedonia. Significant marketing efforts have been made to introduce the country in the international competition playground.

In order to build a strong tourism image, it is exceptionally important to allocate funds for tourism promotion. In the case of Macedonia, substantial progress was made in terms of funding. Namely, in 2005 Macedonia had barely 100,000 EUR for promotion and support of tourism development. This kind of modest support by the government continued until 2012, when approximately 8-10\% increase per year was noted. However, 2013 was registered as the break-point year, and from then onwards a new period was launched. So, 2.3 million EUR were assigned representing 17.5 times bigger budget compared to 2012. Yet, the highest allocated budget ever in Macedonia is registered in 2014, with historical 3.7 million EUR. For 2017, the budget is $7 \%$ lower compared to 2016, but being still over 3 million EUR (Official Gazette, 2016). Yet, even with such amount of money foreseen for tourism promotion, no particular improvements have been made when it comes to developing a tourism brand. This may be the case mostly because branding is a process that should be undertaken before the funds are spent on image-formation and messaging, and hence before promotion plans are decided, advertising campaigns are initiated, web sites built, or public relations paid for. However, Macedonia does this the other way around. Hopefully, the project "One image-one brand for Macedonia as a tourist destination" (OECD, 2016:337) will be accomplished as part of the tourism policy reforms.

Besides the ever growing interest in this significant field, very few studies have investigated the former Yugoslav states from a common perspective. The exception may be found in Hall (2002) who investigated the relationship between national identity and tourism promotion in the case of creating national brands in the former Yugoslav states. Hall (2004) also investigated Slovenia and Croatia, but this time when making a research on their re-branding as Central and Eastern European post communist countries. On the other hand, Macedonia was barely covered. Although this study may add to the current research on green tourism and hotel industry in Macedonia (Petrevska and Cingoski, 2015a, 2015b, 2016), its main contribution lies in the intention to provide insights into the processes and conflicts over efforts to brand Macedonia as an eco-friendly destination. Moreover, this research assesses how Macedonian hospitality industry stakeholders manage the environmental quality, which directly leads to increase of destination's competitiveness. It has a practical significance since it discusses the level of environmental quality of Macedonia as a base for creating a national green tourism brand. The paper mentioned above underlines that tourism branding in Macedonia cannot be conducted successfully without considering the context of "green" tourism.

After the introductory section, the next offers some stylized facts about Macedonia in terms of discussing how green it can be. Section three, presents a brief overview 
of the literature branding and green brands. Section four encompasses the research methodology; section five provides the main findings and discussion, while the final section offers conclusions and recommendations.

\section{Background material: How "green" is it?}

Due to the dispute around what is in and what is out of tourism, it is impossible to regulate it. Therefore, there are no regulations to which tourism destinations self-declare themselves as being sustainable, green, eco-friendly, and so on. Yet, it is more than obvious that tourism is affected by and contributes to the negative impacts on the environment, which makes it a victim as well as a perpetrator. The question is how much, and exactly what should be done to mitigate the negative impacts. With that in mind, it requires various actions including mitigating the greenhouse gasses (GHG) emissions derived especially from transport and accommodation activities; adapting the destinations to the changing environmental conditions; and applying new technologies to improve energy efficiency. However, despite these positive signals, the tourism sector still has a long way to go since human-influenced and human-made environment is not sustainable.

Generally, tourism accounts for about 5\% of GHG emissions worldwide, out of which the largest proportion of $75 \%$ is associated with transportation, whereas $40 \%$ is caused by air traffic (GIZ, 2014:74). Another factor that contributes to the environmental footprint of tourism is accommodation. This sector represents approximately 20\% of GHG emissions generated from tourism (UNWTO-UNEP-WMO, 2008:10). The variety of tourism types, which rely on clean nature and unpolluted environment as core values, impose the necessity to strive for sustainable tourism. Consequently, the hotel management introduce such energy practices that enable environmental protection by reducing carbon dioxide, methane, nitrous oxide and other harmful emissions that provoke global-warming and climate changes. Yet, despite the gain in efficiency, the emissions from global tourism sector are predicted to grow 161\% by 2035 (UNWTO-UNEP-WMO, 2008:36). This actually means that tourism implicates many negative effects that must be prevented or at least, decreased.

Around 90\% of the primary energy in Macedonia is produced from fossil fuels, mainly lignite and heavy crude oil. Moreover the energy sector contributes with over $70 \%$ in total emission of GHG. As a result of these two considerations, enormous pollution of the environment is provoked. Based upon the State of Environment report (EEA, 2015), the total emissions by sectors in Macedonia are due to combustion processes (60\%), transport (30-40\%), and other (less than 5\%). The share of recycled packaging is $12 \%$ of total packaging placed on the market. The air quality notes an abundance of daily limit values of $\mathrm{PM}_{10}$ and $\mathrm{PM}_{2.5}$, which remains a challenge for the future. However, Macedonia continues to adopt and implement EU Acquis.

Being identified as the best way to achieve energy independence and simultaneously take care of introducing and maintaining sustainable development, the renewable energy sources (RES) are heavily promoted as the least pressure production on 
the environment. In 2015, the renewable energy share was $15.9 \%$ of the European energy mix, which is twice as much as it was in 2004 and almost a percentage point more than it was in 2014 (Observ'ER, 2015: 8). While the EU countries are largely investing to increase that share, Macedonia is facing immense problems. Although the transition period passed years ago, Macedonia is still in its starting point when it comes to development of alternative energy sources and the concept of sustainable development. As a country aspiring for the EU membership, Macedonia is obliged to transfer the legislation into its legal system, which consequently lead to preparation of several strategic documents ${ }^{1}$.

Within the latest Strategy for Energy Development, it is foreseen to increase competitiveness in the wider regional energy market and to become high energy efficient (MANU, 2015:1). The objectives proclaimed by the EU in the energy field until 2020 are as follows: improvement of energy efficiency by 20\%, provision of energy from RES in the amount of $20 \%$ of the final energy consumption, and at least a $10 \%$ share of RES in the final energy consumption in traffic (MoE, 2010a:21). In this line, the maximization of the utilization of the RES is noted to be among the strategic priorities, which is proved by the constant increase from 4.2\% in 2012 (UNDP, 2012) to $13.8 \%$ in 2005 in the final energy consumption. Consequently, Macedonia belongs to the countries with a relatively high utilization of this type of energy (MoE, 2010a). Moreover, based on many scenarios within the strategic documents, it is indicated that Macedonia can target a share of RES set at 21\% (MoE, 2010b).

In order to score the national performance and to evaluate how each country protects the ecosystem, the Environmental Performance Index (EPI) is calculated. While for 2016, Finland has taken the top spot, Slovenia is fifth, and Somalia is the last. Macedonia on the other hand is ranked $50^{\text {th }}$ out of 180 countries (Hsu et al., 2016: 18). If it is compared to the neighboring countries in the region, except for Albania $\left(61^{\text {st }}\right)$ and Bosnia and Herzegovina $\left(120^{\text {th }}\right)$, all others are better ranked: Greece $\left(21^{\text {st }}\right)$, Bulgaria $\left(33^{\text {rd }}\right)$, Montenegro $\left(47^{\text {th }}\right)$ and Serbia $\left(48^{\text {th }}\right)$. Although the EPI does not represent comprehensive picture of national environmental issues, it may serve as a baseline for evaluating how far each country is in reaching the global environmental targets. From $89^{\text {th }}$ place in 2014, Macedonia has moved to the first third of the table (50/180), which leads to conclusion that the policymakers undertook serious measures and activities in the line of improving environmental impacts. While Macedonia made progress, many others have worsened considerably. The number of people lacking access to clean water has been nearly cut in half from 960 million in 2000 , to 550 million today. $23 \%$ of countries have no wastewater treatment, 2.4 billion people lack access to sanitation, more than 3.5 billion people live with unsafe air quality etc. (Hsu et al., 2016:12).

1 The most important strategic documents are: the Strategy for Energy Development in the Republic of Macedonia until 2030 (MoE, 2010a), the Strategy for Utilization of Renewable Sources in the Republic of Macedonia by 2020 (MoE, 2010b), and the Strategy for Energy Development in the Republic of Macedonia until 2035 (in Macedonian) (MANU, 2015). 


\section{Literature Review}

Branding is a rapidly growing field of study that has always provoked a large interest among practitioners and academia. Starting with the major benefit that branding offers means for differentiation in market (Gardner and Levy, 1955; Aaker, 1991; Keller, 2003; Pike, 2009), to the dilemma what constitutes the branding process (Park and Petrick, 2006; Blain et al., 2005; Tasci and Kozak, 2006). Some researchers reported on destination image (Gallarza et al., 2002; Pike, 2002), some analyzed the destination positioning (Woodside, 1982; Chacko, 1997; Reich 1997), while others focused on destination slogans (Pritchard, 1982; Richardson and Cohen, 1993; Klenosky and Gitelson, 1997).

With rising concern over the negative tourism impacts on global environment changes, much attention is put on improving the environmental management among all tourism players. Yet, as some jump on the green bandwagon, their actions might do more harm than good to the green image of destination brands. While the green position offers destinations and the opportunity to differentiate, their brand has not received much attention in the literature.

Based on the literature that examines the nature of the green brands, brands classifiable as green are those whose users' primary associations are environmental conservation and sustainable practices (Insch, 2011). Hartmann et al., (2005: 10) characterizes a green brand identity as having "a specific set of brand attributes and benefits related to the reduced environmental impact of the brand and its perception as being environmentally sound." In this line, Keller (2003) argues the necessity to be focused on green values as a feature of green brands, which leads to a clearly defined identity. Aaker and Joachimsthaler (2000) emphasize the brand essence, while First and Khetriwal (2008) note the benefit that appeals to users.

However, the resistance to support green brands, particularly addressing greenwashing (akin to the notion of whitewashing) is noted by Rex and Baumann (2007). The consumer skepticism along with the criticism of greenwashing practices is also elaborated by others (McLaren, 2003; Garrod, 2008).

The vagueness of environmentally sound behaviours reflects the loose definition of a green brand. While the concept of green branding is almost unexplored, much attention has been given to green marketing and green communication.

On the other hand, tourism and ecotourism are obvious associations made with national branding. Keeping in mind that today's tourists are highly aware of the negative tourism impacts on the environment, many countries have started their promotion as eco-friendly destinations. The contemporary tourists often search for unique features to discover first-hand something new or at least interesting. They abandon tourist destinations in poor environmental conditions and trace for hospitality industry establishments with ecolabel, eco-certificate, and certificate for energy efficiency. 
That forced hoteliers to rearrange priorities and to make the establishments green, due to the fact that environmentally-conscious and adequately informed tourists are more willing to pay than others (Han and Kim, 2010; Kostakis and Sardianou, 2011) and rather consume green products and stay at green hotels (D'souza and Taghian, 2005; Chen and Tung, 2014). Yet, tourists are willing to participate in energy reduction efforts if it does not greatly diminish their holiday experience, if it is easy, or if it saves them money (UNWTO-UNEP-WMO, 2008). Consequently, hotels, as primary accommodation facilities, urge to apply environmental protection programs for reducing the energy consumption, recycling and composting food scraps (Bruns, 2000; Dodd et al., 2001; Bowe, 2005; Chen et al., 2005; Karagiorgas et al., 2006; Lu et al., 2012; Radwan et al., 2012; Xin et al., 2012; Kallbekken and Saelen, 2013; Pirani and Arafat, 2014).

Recently, worldwide hotels have noticed the benefits of being transformed to eco-friendly hotels, thus leading to increased demand and competitive advantage (Vazques et al., 2001; Bohdanowicz, 2005a, 2005b; Le et al., 2006).

\section{Methodological Notes}

The primary objective of the study is to determine the level of environmental quality of Macedonia as a base for creating a national green tourism brand. To achieve it, the study investigates the perception of hotel management in application of ecopolicies and environmental practices by exploring standard indicators. Moreover, an assessment is made on how hotel management copes with the environmental quality, which directly leads to an increase of the destination's competitiveness.

The study took quantitative and qualitative methods. The quantitative method consisted of an online survey among 127 managers and department supervisors of three, four and five-star hotels in Macedonia, conducted in May 2015. It was based on 32 indicators already discussed in YCELP-CIESIN (2012). The questionnaire was structured in three sections (Environmental policy; Usage and savings of resources; and Benefits and constraints) with two-choice questions and a five-point Likert scale. The low response rate of $35.4 \%$ was expected due to the lack of personal contact when conducting an online survey. By applying the Categorical Principal Components Analysis (CATPCA) technique, the number of variables was reduced, while the reliability of the components was checked by the Cronbach Alpha. The scores of the perception components were compared by Kruskal-Wallis tests, while the indicators for benefits and constraints were perceived by calculating medians in the components scores.

In the qualitative method, a consultation of secondary sources was conducted. It included a review of literature and websites, thus adopting a multidisciplinary approach. Information collected via these procedures enabled triangulation and validation of data. 


\section{Findings and Discussion}

As noted, the questionnaire was structured in three sections. Section I comprised of 12 questions defining the environment policy $(a=0.81$; average score of the mode $=3$ i.e. medium level of influence). There is a variety of tools available that can be used to implement efficient environmental policy and environmental management system (EMS). Among the investigated, the top three items perceived by the managers are: Prevention interventions (0.834); Employees' training (0.718); and medium knowledge of the environmental protection standard ISO 14000 (0.664). There are also over a hundred global and regional certification programs for sustainable tourism (e. g. Green Globe, Green Key, TourCert, Travelife) which support hotel management in the establishment of appropriate EMS through the use of labels (Font, 2002). In this line, Ecolabels and Eco certificates are widespread tools for policy and marketing tourism strategies and are used frequently to show quests' reliability. Additionally, they may add credibility to green brands, but are unlikely to actively communicate the array of functional and emotional benefits consumers, other than the greenest seek. In the case of Macedonia, $60.9 \%$ of the surveyed hotels do not have Ecolabels and $64.6 \%$ do not hold an Eco certificate. This is opposite to some facts that certification programs provide benefits and impose more efficient operations (Haaland and Aas, 2010). It was also found that Macedonian hotel management rarely prepares written plans for environmental protection which is not in favor of supporting the European environmental impact assessment regulation. This legislation started to develop in the 1970 s and since then, many documents, action plans and standards have been established by the European Union. Besides industry, energy, transportation and agricultural sections, tourism is also introduced as a segment that must conform to the Fifth Environmental Action Program. Due to the fact that Macedonia is a candidate country for EU membership, much attention should be put so that hospitality industry stakeholders meet the internationally set standards.

Section II included 11 questions for assessing the usage and savings of resources $(a=0.74$; average score of the mode $=4$ i.e. strong level of influence). Environmental management may serve as an effective strategy for hotels and destinations to create additional value in the long run. This was found to not be the case with Macedonia. The findings are alarming since they point to extremely limited use of alternative energy sources and new innovative approaches in saving energy consumption. The loadings for the items referring geothermal energy, bio fuel, photocell lighting, "smart rooms", dimming system and the use of treated water, are far below the critical values. Hence, Macedonian hotel management lack EMS, which reduces resource use which cuts down operational costs, which is becoming increasingly important especially considering the ever-increasing resource prices (e.g. energy prices) or local shortages of resources (e.g. water). On the other hand, the awareness of quests is constantly rising. Namely, the signs in hotel bathrooms that encourage guests to use their towels more than once to contribute to saving the environment are part of Macedonian hotels' policy. This is known as one of the oldest environmental protection strategies in tourism, initiated for about thirty years now. By saving money due to less dirty laundry to wash, it may contribute to environmental protection. 
Section III covered 10 questions in the line of measuring the managerial perception on benefits and constraints for applying the energy consumption concept $(a=0.63$; average score of the mode $=4$ i.e. strong level of influence). As per benefits, the top three items perceived by the managers are: Environmental protection (0.642); Improved image (0.612), and Enhanced competitiveness (0.514). They are assessed as strong determinants for introducing and sustaining energy efficiency practices. The summarized results confirm the findings as in Cunningham (2005), Erdogan and Baris (2007), as well as Trung and Kumar (2005) that although being aware of the importance of the energy consumption and environmental protection, its stewardship is not a top priority. Namely, the problem is the gap between the environmental awareness and the daily practice of the hotel management.

As per constraints, the top three items being perceived as determinants with medium influence are: Lack of subsidies (0.567); Cost increase (0.511); and Technical limits (0.447). This supports the market postulate for minimizing the costs and maximizing the profit so that the hotel can survive. The blame is put on the restricted financial resources and high operation costs for the limited application of RES. Due to the economic and socio-political problems, the hotel management is often faced with existential difficulties. Hence, the environmental issues have just recently come to attention. This is very different when compared to the Scandinavian countries where the environmental protection is of high importance and has long received political and financial support at local and national level.

When calculating the nonparametric correlations between hotel's type and managerial perception score (in terms of the components resulting from the CATPCA), we found:

(i) Presence of positive correlation between hotel type and managerial perception; and

(ii) Positive and significant correlation between five-star hotels and the environmental practices.

\section{Conclusion and Recommendations}

Contemporary tourists expect an environmentally responsible hotel management to meet their environmental needs and expectations. This provokes a profound modification in the hotel industry which has steadily recognized the necessity for becoming greener in order to be well positioned on the competitive tourism market. Consequently, hotels (as leading accommodation facilities) are rapidly becoming environmentally responsible. By developing the idea of having eco-hotels, a "green" brand may be initiated which may position the country positively to be differentiated from competitors in a way that authentically resonates across stakeholders.

This research found that the improved image along with the enhanced competitiveness are strong determinants, provoking better interest than the increase of number of guests. Yet, large number of surveyed hotel managers lack measures to reduce 
the conventional energy use and replace it with RES. Although being fully aware of the importance of the environmental concept, this is not the managerial priority of Macedonian hotels.

Based on the survey findings, we may conclude that Macedonian hotel management possesses relatively low level of environmental quality, resulting in poor and insufficient base for initiating creation of a national green tourism brand. Therefore, some recommendations may be followed which may allow creating more pro-environmental marketing strategies to enhance country's distinctiveness. The hotel management must take steps to become more environmentally sustainable, even if initially there are costs for the implementation of the changes (technological, behavioral and organizational) in their everyday business, which will lead to cutting the operating costs and resulting in constantly improvement of the efficiency. This should be done even if tourists do not demand it as part of their expectations. Additionally, Macedonia can do more frequent penalizing of the environmentally unsound concepts practiced in hotels. In the same line, in order to meet tourism sustainable development goals, hotel management must find a way to avoid the fragmentation driven by the competitiveness, and work along in order to shape policies, not just react to them. This fully fits with the findings of Mihalič (2000) and Dwayer et al., (2012) who state that the emerging destinations are by far challenged to achieve competitive advantage.

In the line of assisting Macedonia to be a step closer to be identified as "green", some initial actions are recommended. For example:

- To set targets and benchmarking, as well as to apply for eco certification;

- To motivate tourism employees, tourists and all other stakeholders in tourism development, through awareness-raising and through incentives for energy reduction;

- To support engagement of architects and urbanists in process of planning, designing and refurbishment of energy efficient architecture;

- To install energy-efficient devices;

- To use alternative fuels (e.g., biodiesel) and RES (e.g., wind, photovoltaic, solar, thermal, geothermal, biomass and waste);

- To integrate emission management (including supply chain management) and wider environmental management (e.g., waste);

- To develop an environmental 'Code of Ethics', (checklist or criteria that a hotel can provide to its suppliers to help them perform their services to the sector in an environmentally respectful manner;

- To incluse energy-efficiency and renewable energy use support programmes in national tourism policies and development plans (Agenda 21, guidelines, regulations, incentives, planning, capacity building, stakeholder cooperation) etc.

Furthermore, in the line of developing a brand, Macedonia must conduct an extensive research in consultation with stakeholders, tour operators and potential tourists. The study recommends that three strategies may be taken in consideration when assisting Macedonia to be branded as "green" tourism destination: 
(1) Reducing energy use by tourism sector, which may be achieved by altering tourism development, in the first line by increasing the length of stay, thus effectively reducing the carbon footprint per tourist day and increase the economic opportunity for the country;

(2) Improving energy efficiency particularly in the accommodation, which may be achieved by introducing more rapid new technologies and environmentally proactive management system; and

(3) Increase the use of RES, which are relevant for tourism, economical, and technically feasible.

The capacity and capability of introducing RES may become an important criterionon for the level of the sustainable development of Macedonia, thus contributing to its national green branding. It does not mean just having a cute logo and a tag line. It means much more and serves for a deeper purpose - to position the country so that it can achieve the maximum success in the world system. This requires government actions for unprecedented political commitment and effective policy design and implementation. Only the government knows the full agenda of the country and has the power and resources to lead the country in a branding process. That is the only way Macedonia may establish and maintain competitive and sustainable development if it aspires to be based on tourism. By initiating the "green electricity" production, it may be a step closer to creating preconditions for green tourism development as well. Instead of having tourism and hospitality facilities that are highly dependent on fossil fuels, the inclusion of the renewable energy for energy production may allow improved and protected environment being detected as one of the preconditions for developing green tourism.

The study results are subject to several limitations, so further improvements may be undertaken on theoretical and practical level.

- First, the assessment is based on a relatively small sample of hotels, which may put a doubt on the representation of the findings for the country in general. The investigation may employ multiple models and theories related to the green branding;

- Secondly, it applied relatively a small set of indicators to trace how "green" Macedonian hotels are. Additional examinations may be done by introducing more criteria for assessing the application of energy policies and environmental programs;

- Thirdly, the selected respondents represent just one interest group, so improvements may include other aspects (e.g. hotel's employees, hotel's guests, etc.). By combining and comparing responses, a more comprehensive overview may be accomplished.

Yet, the study may assist in better understanding of the possibilities for branding Macedonia as a destination that provides green tourism, upon which specific communication strategies may be set. Overall, the research generates useful findings and points to valuable directions for further work in the field of tourism branding. 


\section{References}

1. Aaker, D. A. (1991). Managing Brand Equity. New York: Free Press.

2. Aaker, D. A. and Joachimsthaler, E. (2000). Brand Leadership. NY: The Free Press.

3. Bohdanowicz, P. (2005a). Environmental awareness and initiatives in the Swedish and Polish hotel industries - Survey results. International Journal of Hospitality Management, 21: 57-66.

4. Bohdanowicz, P. (2005b). European hoteliers' environmental attitudes: Greening the business. Cornell Hotel and Restaurant Administration Quarterly, 46 (2): 188-204.

5. Bowe, R. (2005). Going green: Red stripe, yellow curry and green hotels. The Environmental Magazine, 16 (1): 52-53.

6. Blain, C.; Levy, S. E. and Ritchie, J. R. B. (2005). Destination branding: Insights and practises from destination management organizations. Journal of Travel Research, 43: 328-338.

7. Bruns, R. (2000). Do not throw in the towel. Lodging, 26 (2): 88.

8. Caldwell, N. and Freire, J. R. (2004). The difference between branding a country, a region and a city: Applying the Brand Box Model. Brand Management, 12 (1): 50-61.

9. Chacko, H. E. (1997). Positioning a tourism destination to gain a competitive edge. Asia Pacific Journal of Tourism Research, 1 (2): 69-75.

10. Chen, M-F. and Tung, P-J. (2014). Developing an extended Theory of Planned Behavior model to predict consumers' intention to visit green hotels. International Journal of Hospitality Management, 36: 221-230

11. Chen, J. S.; Legrand, W. and Sloan, P. (2005). Environmental performance analysis of German hotels. Tourism Review International, 9 (1): 61-68.

12. Cunningham, P. (2005). Valuing for Ogasawara: Implications for sustainable practices within the accommodation sector. Asia Pacific Journal of Tourism Research, 10 (2): 207-216.

13. Dodd, T. H.; Hoover, L. C. and Revilla, G. (2001). Environmental tactics used by hotel companies in Mexico. International Journal of Hospitality $\&$ Tourism Administration, 1 (3/4): 111-127.

14. D'Souza, C. and Taghian, M. (2005). Green advertising effects on attitude and choice of advertising themes. Asian Pacific Journal of Marketing and Logistics, 17: 51-66.

15. Dwayer, L.; Knežević Cvelbar, Lj.; Edwards, D.; Mihalič, T. (2012). Fashioning a destination tourism future: The case of Slovenia. Tourism Management, 33: 305-316.

16. EEA - European Environment Agency. (2015). The European Environment State and outlook 2015, Countries and regions: the Former Yugoslav Republic of Macedonia, SOER 2015.

17. Erdogan, N. and Baris, E. (2007). Environmental protection programs and conservation practices of hotels in Ankara, Turkey. Tourism Management, 28: 604614.

18. Font, X. (2002). Environmental certification in tourism and hospitality: progress, process and prospects. Tourism Management, 23: 197-205. 
19. First, I. and Khetriwal, D. S. (2008). Exploring the relationship between environmental orientation and brand value: is there fire or only smoke?. Business Strategy and the Environment, 19 (2): 90-103.

20. Gallarza, M. G.; Saura, I. G. and Garcia, H. C. (2002). Destination image - towards a conceptual framework. Annals of Tourism Research, 29 (1): 56-78.

21. Garrod, G. (2008). Greenwash. In: M. Lück (Ed.), The Encyclopaedia of Tourism and Recreation in Marine Environments, CABI.

22. Gardner, B. B. and Levy, S. J. (1955). The product and the brand. Harvard Business Review, March-April: 33-39.

23. GIZ-Deutsche Gesellschaft für Internationale Zusammenarbeit. (2014). Tourism Planning in Development Cooperation: A Handbook - Challenges - Consulting Approaches - Practical Examples - Tools. Bonn and Eschborn.

24. Haaland, H. and Aas, O. (2010). Eco-tourism certification - Does it make a difference? A comparison of systems from Australia, Costa Rica and Sweden. Scandinavian Journal of Hospitality and Tourism, 10 (3): 375-385.

25. Hall, D. (2002). Brand development, tourism and national identity: The re-imaging of former Yugoslavia. Brand Management, 9: 323.

26. Hall, D. (2004). Branding and national identity: the case of Central and Eastern Europe, in: Morgan, N.; Pritchard, A. and Pride, R. (Eds.). Destination branding: Creating the unique destination proposition, Oxford: Elsevier, (pp. 111-127).

27. Han, H., and Kim, Y. (2010). An investigation of green hotel customers' decision formation: developing an extended model of the theory of planned behavior. International Journal of Hospitality Management, 29: 659-668.

28. Hartmann, P.; Apaolaza Ibanez, V. nad Forcada Sainz, J. F. (2005). Green branding effects on attitude: functional versus emotional positioning strategies. Marketing Intelligence and Planning, 23 (1): 9-29.

29. Hsu, A. et al. (2016). 2016 Environmental Performance Index. New Haven, CT: Yale University.

30. Insch, A. (2011). Conceptualization and anatomy of green destination brands. International Journal of Culture Tourism and Hospitality Research, DOI: 10.1108/17506181111156970.

31. Kallbekken, S. and Saelen, H. (2013). "Nudging" hotel guests to reduce food waste as a win-win environmental measure. Economic Letters, 119: 325-327.

32. Karagiorgas, M.; Tsoutsos, T.; Drosoua, V.; Pouffary, S.; Pagano, T.; Lara, G. L. (2006). HOTRES: Renewable energies in the hotels. An extensive technical tool for the hotel industry. Renewable and Sustainable Energy Reviews, 10 (3): 198224.

33. Kavaratzis, M. (2004). From city marketing to city branding: Towards a theoretical framework for developing city brands. Place Branding and Public Diplomacy, 1 (1): 58-73.

34. Keller, K. L. (2003). Strategic Brand Management. Upper Saddle River, NJ: Prentice Hall.

35. Klenosky, D. B. and Gitelson, R. E. (1997). Charateristics of effective tourism promotion strategies. Annals of Tourism Research, 24 (1): 235-2238.

36. Kostakis, I. and Sardianou, E. (2011). Which factors affect the willingness to pay for renewable energy?, Policy Issues, World Renewable Energy Congress 2011-Sweden, 8-13 May 2011, Linkoping, Sweden, 2578-2585. 
37. Kotler, P.; Haider, D. H. and Rein, I. (1993). Marketing places: Attracting investment, industry and tourism to cities, states and nations. New York: The Free Press.

38. Le, Y., Hollenhorst, S.; Harris, C.; McLaughlin, W.; Shook, S. (2006). Environmental management: A study of Vietnamese hotels. Annals of Tourism Research, 33 (2): 545-567.

39. Lu, S.; Wei, S.; Zhang, K.; Kong, X.; Wu, W. (2012). Investigation and analysis on the energy consumption of starred hotel buildings in Hainan Province, the tropical region of China. Energy Conversion and Management, 75: 570-580.

40. MANU - Macedonian Academy of Sciences and Arts. (2015). Strategy for Energy Development in the Republic of Macedonia until 2035 (in Macedonian). Skopje: Research Center for Energy and Sustainable Development.

41. Mihalič, T. (2000). Environmental management of a tourist destination: A factor of tourism competitiveness. Tourism Management, 21: 65-78.

42. MoE - Ministry of Economy, Government of the Republic of Macedonia. (2010a). Strategy for Energy Development in the Republic of Macedonia until 2030, Skopje.

43. MoE - Ministry of Economy, Government of the Republic of Macedonia. (2010b). Strategy for Utilization of Renewable Sources in the Republic of Macedonia by 2020, Skopje.

44. McLaren, D. (2003). Rethinking Tourism and Ecotravel. Kumarian Press.

45. Observ'ER. (2015). The State of Renewable Energies in Europe, $15^{\text {th }}$ EurObserv'ER Report.

46. Official Gazette of the Republic of Macedonia. (2016). Program for promotion and support of tourism for 2017. No. 192, 17.10.2016, Skopje.

47. OECD. (2016). Former Yugoslav Republic of Macedonia (FYROM), in: OECD Tourism Trends and Policies 2016. Paris: OECD Publishing.

48. Park, S. Y. and Petrick, J. F. (2006). Destinations' perspectives of branding. Annals of Tourism Research, 33 (1): 262-265.

49. Petrevska, B. and Cingoski, V. (2015a). Environmental protection and energy efficiency concept in five star hotels in Macedonia, Conference proceedings from $6^{\text {th }}$ International Symposium on Industrial Engineering, Belgrade, Serbia, 24-25 September 2015, 210-213.

50. Petrevska, B. and Cingoski, V. (2015b). Renewable energy for sustainable tourism: assessment of Macedonian hotels, Conference proceedings from ICONBEST 2015: Economic analysis of global trends in tourism, finance, education and management, Skopje, Macedonia, 9-10 October, 2015, 141-151.

51. Petrevska, B. and Cingoski, V. (2016). Can Macedonian hotels be green: the evidence of hotel "Flamingo" - Gevgelija, Macedonia, Book of Abstracts from the International conference GREDIT 2016, Skopje, Macedonia, 30 March - 2 April, 2016, 142.

52. Pike, S. D. (2002). Destination Image Analysis: A Review of 142 Papers from 1973- 2000. Tourism Management, 23 (5): 541-549.

53. Pike, S. D. (2009). Destination brand positions of a competitive set of near-home destinations. Tourism Management, 30 (6): 857-866.

54. Pirani, S. A. and Arafat, H. A. (2014). Solid waste management in the hospitality industry: A review. Journal of Environmental Management, 146: 320-336. 
55. Pritchard, G. (1982). Tourism Promotion: big business for the States. The H.R.A. Quarterly, 23 (2): 48-57.

56. Radwan, H. R.; Jones, E. and Minoli, D. (2012). Solid waste management in small hotels: a comparison of green and non-green small hotels in Wales. Journal of Sustainable Tourism, 20 (4): 533-550.

57. Real, J. L. R. (coordinator). (2016). Destination branding - A compilation of success cases. IBRAVE project, European Commission.

58. Reich, A. Z. (1997). Improving the effectiveness of destination positioning. Tourism Analysis, 2: 37-53.

59. Rex, E. and Baumann, H. (2007). Sustainable production and consumption: making the connection. Journal of Cleaner Production, 15 (6): 567-576.

60. Richardson, J. and Cohen, J. (1993). State slogans: the case of the missing USP. Journal of Travel and Tourism Marketing, 2 (2/3): 91-109.

61. Tasci, A.D.A. and Kozak, M. (2006). Destination brands vs destination images: Do we know what we mean?. Journal of Vocation Marketing. 12 (4): 299-317.

62. Trung, D. N. and Kumar, S. (2005). Resource use and waste management in Vietnam hotel industry. Journal of Cleaner Production, 13: 109-116.

63. UNDP-United Nations Development Program. (2012). Renewable Energy Snapshots: the Former Yugoslav Republic of Macedonia - key information.

64. UNWTO-UNEP-WMO, United Nations World Tourism Organization, United Nations Environment Program, World Meteorological Organization. (2008). Climate change and tourism: Responding to Global Challenges, UNWTO, Madrid.

65. Vazques, R.; Santos, M. and Alvarez, L. (2001). Market orientation, innovation and competitive strategies in industrial firms. Journal of Strategic Marketing, 9: 69-90.

66. Woodside, A. G. (1982). Positioning a province using travel research. Journal of Travel Research, Winter: 2-6.

67. Xin, Y.; Lu, S.; Zhu, N.; Wu, W. (2012). Energy consumption quota of four and five star luxury hotel buildings in Hainan province, China. Energy and Buildings, 45: 250-256.

68. YCELP, CIESIN. (2012). Environmental Performance Index 2012, Yale Center for Environmental Law and Policy (YCELP) and Center for International Earth Science Information Network (CIESIN), Columbia University. 


\section{Biljana Petrevska}

Sveučilište Goce Delčev, Fakultet za turizam i poslovnu logistiku, Štip, Makedonija

e-mail: biljana.petrevska@ugd.edu.mk

\section{Vlatko Cingoski}

Sveučilište Goce Delčev, Elektrotehnički fakultet, Štip, Makedonija

e-mail:vlatko.cingoski@ugd.edu.mk

\section{Brendiranje zelenog turizma u Makedoniji}

\section{Sažetak}

Turizam je brzo rastuća djelatnost, stoga nacionalno brendiranje može biti dio učinkovite strategije u upravljanju nacionalnim rastom u turizmu. Pozitivan imidž zemlje jedan je od osnovnih temelja promidžbe, što ilustrira potrebu ulaganja u brendiranje zemlje kao dijela strategije izgradnje toga imidža. Članak koristi primarne i sekundarne podatke u pružanju uvida u procese i probleme koji prate brendiranje Makedonije kao ekološki osviještenog odredišta. Autori istražuju percepciju hotelijerskog menadžmenta po pitanju primjene koncepata zaštite okoliša i obnovljivih izvora energije. U istraživanju su primijenjene: (1) kvantitativne metode, korištenjem proračuna srednjih vrijednosti mjerenja ekopolitike i praksa zaštite okoliša te (2) kvalitativne metode, konzultiranjem sekundarnih izvora podataka. Procjenjuje se na koji način ugostitelji upravljaju utjecajem svojih djelatnosti na okoliš, budući da to izravno može dovesti do povećanja konkurentnosti destinacije. Glavni je cilj utvrditi razinu kvalitete okoliša Makedonije kao temelja za stvaranje nacionalnog brenda zelenog turizma. Istraživanje je kod velikog broja hotela pokazalo nedostatak mjera za smanjenje konvencionalne uporabe energije i njenu zamjenu obnovljivim izvorima energije. Iako su svjesni važnosti koncepta energetske učinkovitosti, te mjere nisu prioritet menadžera makedonskih hotela. Ti rezultati mogu pomoći u daljnjim koracima izrade marketinške strategije kako bi se poboljšala prepoznatljivost posebnosti zemlje. Glavni je doprinos ovog članka u tome da predstavlja početak izrade okvira za uvođenje konkurentne ekološke strategije u hotelskim objektima kako bi se doprinijelo formiranju zelenog identiteta Makedonije.

Ključne riječi: promocija, brendiranje, životna okolina, zeleni turizam. 